\title{
Light and dark carbon uptake by Dinophysis species in comparison to other photosynthetic and heterotrophic dinoflagellates
}

\author{
Edna Granéli ${ }^{1, *}$, Donald M. Anderson ${ }^{2}$, Per Carlsson ${ }^{1,2}$, Serge Y. Maestrini ${ }^{3}$ \\ ${ }^{1}$ Institute of Natural Sciences, University of Kalmar, S-39129 Kalmar, Sweden \\ ${ }^{2}$ Biology Dept, Woods Hole Oceanographic Institution, Woods Hole, Massachusetts 02543, USA \\ ${ }^{3}$ CREMA-L'Houmeau (CNRS-IFREMER), BP 5, F-17137 L'Houmeau, France
}

\begin{abstract}
The marine dinoflagellate genus Dinophysis includes species that are the causative agents of diarrhetic shellfish poisoning (DSP). Recent findings indicate that some Dinophysis species are mixotrophic, i.e. capable of both autotrophic and heterotrophic nutrition. We investigated inorganic (and organic) carbon uptake by several species of Dinophysis in the light and dark using the 'single-cell ${ }^{14} \mathrm{C}$ method', and compared uptake rates with those of photosynthetic Ceratium species and heterotrophic dinoflagellates in the genus Protoperidinium. Experiments were conducted with water from the Gullmar Fjord and from the Koster Strait (Swedish west coast). Nutrient-enriched phytoplankton from surface water samples were concentrated $(20$ to $70 \mu \mathrm{m})$ and incubated at in situ temperature under artificial light conditions with high concentrations of inorganic ${ }^{14} \mathrm{C}\left(1 \mu \mathrm{Ci} \mathrm{ml} l^{-1}\right)$. Individual cells of each desired species were manually isolated under a microscope and transferred to scintillation vials. C. tripos showed net ${ }^{14} \mathrm{C}$ uptake only during light periods, whereas both $C$. lineatum and $C$. furca showed ${ }^{14} \mathrm{C}$ uptake in the light as well as uptake (and sometimes losses) in the dark. Dinophysis species had similar carbon fixation rates in light compared to Ceratium species. For D. acuminata and $D$. norvegica, net carbon uptake occurred in both light and dark periods. $D$. acuta showed a loss of carbon in the dark in one experiment, but in another, dark $C$ uptake was significantly higher than uptake in light. When exposed to light, $C$. furca, $D$. norvegica and $D$. acuta had high specific carbon uptake rates. Growth rates for the different species were calculated from ${ }^{14} \mathrm{C}$ uptake by the cells during the first hours of incubation in light. $D$. acuminata and $D$. norvegica had similar maximum growth rates, 0.59 and $0.63 \mathrm{~d}^{-1}(\mu)$; the maximum growth rate of $D$. acuta was lower $\left(0.41 \mathrm{~d}^{-1}\right)$. The positive dark carbon uptake by Dinophysis may suggest a mixotrophic mode of nutrition. In one experiment, both $D$. norvegica and $D$. acuta showed a significantly higher carbon uptake in a dark bottle than in a light bottle, which would be consistent with uptake of ${ }^{14} \mathrm{C}$-labeled organic matter by $D$. norvegica and $D$. acuta. Demonstration of direct uptake of dissolved and particulate organic matter would provide conclusive evidence of mixotrophy and this will require the development of new protocols for measuring organic matter uptake applicable to Dinophysis in the natural assemblages.
\end{abstract}

KEY WORDS: Dinophysis - Growth rate $\cdot$ Mixotrophy $\cdot$ Carbon uptake $\cdot$ Ceratium $\cdot$ Protoperidinium

\section{INTRODUCTION}

Several species in the marine dinoflagellate genus Dinophysis are known to produce toxins responsible for diarrhetic shellfish poisoning (DSP) (Yasumoto et al. 1980, Krogh et al. 1985, Sedmak \& Fanuko 1991, Lembeye et al. 1993, Subba Rao et al. 1993). The genus

•E-mail: edna.graneli@ng.hik.se occurs in many different tropical and temperate marine waters over a wide range of salinities (Hallegraeff \& Lucas 1988, Hallegraeff 1993). Much of what is known of the ecology, biology, and toxicology of Dinophysis comes from studies of natural populations (Edler \& Hageltorn 1990, Delmas et al. 1992, Carlsson et al. 1995) because it is not yet possible to culture any of the species for extended periods in the laboratory (Sampayo 1993, Maestrini et al. 1995, Subba Rao 
1995). The species linked directly to DSP $(D$. acuta, $D$. acuminata, $D$. norvegica, $D$. fortii, $D$. mitra) are all photosynthetic and contain functional chloroplasts. Nevertheless, Dinophysis species do not survive when cultured in light using culture media that support the growth of many other photosynthetic phytoplankton species. This may reflect the absence of some trace inorganic element missing from most culture media, such as cobalt or selenium, which have been shown to be essential elements for many phytoplankton species (Keller \& Guillard 1985, Harrison et al. 1988, Edvardsen et al. 1990, Granéli \& Haraldsson 1993, Granéli \& Risinger 1994). Thus far, however, addition of selenium, cobalt or other trace elements has not made it possible to culture Dinophysis species (Maestrini et al. 1995). Alternatively, these species may be osmotrophic, relying on dissolved organic materials to supplement inorganic uptake. Many phytoplankton species are osmotrophic to a small extent, requiring vitamins such as biotin, B12, or thiamin that they cannot synthesize themselves (see Bonin \& Maestrini 1981). Here again, addition of many different organic supplements to culture media has not resulted in longlived cultures of several Dinophysis species (D. cf. acuminata, $D$. acuta and $D$. sacculus; Maestrini et al. 1995).

A third possibility is that the DSP-causing Dinophysis species are phagotrophic, meaning that they are able to ingest particles, perhaps as a survival strategy during times when photosynthesis and/or osmotrophy cannot support continued growth. One species of the genus Dinophysis (D. rotundata) lacks chloroplasts and is completely heterotrophic, feeding phagotrophically (Hansen 1991). Jacobson \& Andersen (1994) have found food vacuoles in $D$. norvegica and $D$. acuminata, suggesting that a phagotrophic feeding mechanism exists.

The idea that photosynthetic phytoplankton might be able to supplement their nutrition through the direct uptake and utilization of organic material is not new. Evidence from older studies is based exclusively on microscopic observations (e.g. Manton \& Parke 1962, Pintner \& Provasoli 1968) or traditional bioassay experiments (Bonin \& Maestrini 1981, Granéli et al. 1985). Study of the use of dissolved organic material or phagotrophic ingestion of algae or bacteria by photosynthetic phytoplankton species has recently gained new momentum with the advent of techniques such as fluorescent or radioactive labeling of dissolved/particulate substances (Rivkin \& Putt 1987, Jones et al. 1993).

To demonstrate phagotrophy in phytoplankton, either radioactive ${ }^{14} \mathrm{C}$-labeled bacteria (Nygaard \& Hessen 1990, Nygaard \& Tobiesen 1993), labeled algae or bacteria (Nygaard \& Hessen 1990), fluorescent beads (Porter 1988) or green flagellates (Jones et al.
1993) are given as a food source to the species in question. The above studies were typically performed with monocultures. Given our objective to gain information on the biology of the dinoflagellate genus Dinophysis, it was necessary to work with natural phytoplankton communities since these species cannot yet be cultured in the laboratory.

In an attempt to provide information on the possible heterotrophy of this genus, a series of experiments was performed using the natural phytoplankton communities containing several chloroplast-bearing Dinophysis species. Entire phytoplankton communities from waters along the East Skagerrak on the Swedish west coast were labeled with ${ }^{14} \mathrm{C}$, and incubated in the laboratory for several days. Thereafter Dinophysis and other dinoflageliate species were isolated as single cells, placed in scintillation vials and species-specific ${ }^{14} \mathrm{C}$ uptake determined during light and dark periods. Uptake by Dinophysis species was compared to the uptake by the other dinoflagellates exposed to the same conditions, including photosynthetic and heterotrophic species.

\section{MATERIALS AND METHODS}

Three experiments using East Skagerrak water containing natural phytoplankton communities were performed in 2 different years. Expts 1 and 2 (October 1992) were performed at the Tjärnö Marine Biological Station with water collected $4 \mathrm{~km}$ off the Koster Strait (Swedish west coast). Expt 3 (September 1993) used water from the Gullmar Fjord, outside the Kristineberg Marine Research Station.

One gallon (ca 4.5 l) polycarbonate bottles were filled with 41 of seawater containing the phytoplankton communities which had been concentrated using aluminum frames $(60 \times 40 \mathrm{~cm})$ to which nylon mesh was attached (see Maestrini et al. 1995 for details). By restricting the flow through the meshes using holes bored into the open box on which they were placed, cells were always suspended in a large volume of water and shear rates were low through the mesh. This has been shown to be a gentle means of concentrating nopulations and leaves most dinoflagellate cells swimming. Size fractionation was 20 to $70 \mu \mathrm{m}$ in Expt 1 and 40 to $70 \mu \mathrm{m}$ in Expts 2 and 3. The $40 \mu \mathrm{m}$ net was used in Expts 2 and 3 in order to let as many small cells as possible pass, since small cells present in large quantities made the rinsing of the isolated radioactive cells more laborious in Expt 1.

Before the experiments started, the concentrated phytoplankton were placed in $10 \mathrm{l}$ polycarbonate bottles incubated in a cool room [temperature $16^{\circ} \mathrm{C}$, light $100 \mu \mathrm{mol} \mathrm{m} \mathrm{m}^{-2} \mathrm{~s}^{-1}$ (photosynthetically active radiation, 
PAR)] for at least $1 \mathrm{~d}$. The algae swimming at the top of the bottles were then gently siphoned into the experimental bottles. In this way we were sure that only healthy cells that had survived the concentration process would be used in the experiments.

For Expts 1 and 2, a timer coupled to the lights was used to control light and dark hours. In Expt 3, double black plastic sheets were wrapped around the bottles to make them dark. In order to investigate dark uptake during a longer period without shaking and sampling, 1 bottle was left undisturbed in the dark in Expt 3. To accomplish this, 1 l was removed from the 1 gallon (4.5 I) bottle (Bottle A) at Hour 29 and poured into a polycarbonate bottle (Bottle B) covered with 2 layers of thick black plastic and kept in the dark under the same conditions as the original bottle, but without shaking. This prolonged darkness by $40 \mathrm{~h}$ until the last experimental sampling occasion (Hour 69).

The temperature, salinity and light intensities in the 3 experiments were as follows: Tjärnö 1992, Expt 1: $10^{\circ} \mathrm{C}, 28.5 \%$, $67 \mu \mathrm{mol} \mathrm{m} \mathrm{m}^{-2} \mathrm{~s}^{-1}$; Expt 2: $10^{\circ} \mathrm{C}, 31 \%$, $67 \mu \mathrm{mol} \mathrm{m} \mathrm{m}^{-2} \mathrm{~s}^{-1}$; Kristineberg 1993 , Expt 3: $11.5^{\circ} \mathrm{C}$, $30 \%, 100 \mu \mathrm{mol} \mathrm{m}^{-2} \mathrm{~s}^{-1}$. The chosen temperatures were the approximate in situ temperatures when the water was sampled and the light levels were representative for the water at 3 to $6 \mathrm{~m}$ depth in situ at noon.

To each bottle ${ }^{14} \mathrm{C}$-labeled bicarbonate was added to give a final concentration of $1 \mu \mathrm{Ci} \mathrm{ml} \mathrm{m}^{-1}$ ('25 mCi stock solution', Amersham). The method used to isolate cells following the incubations was that of Rivkin \& Seliger (1981) with the following modifications: after incubating in light or dark, the phytoplankton cells were concentrated in a fume hood on a $6 \mathrm{~cm}$ diameter, $10 \mu \mathrm{m}$ mesh size nylon net. The cells retained on the net were then washed extensively with $4 \mathrm{l}$ of Whatman GF/C filtered seawater in order to remove excess dissolved ${ }^{14} \mathrm{C}$. The collected plankton were then washed from the net and into a $10 \mathrm{ml}$ test tube using filtered seawater from a squirt-bottle. The tube of cells was placed in a cooler containing crushed ice. Single cells of each target species were then isolated under the microscope from Sedgewick-Rafter or Palmer-Maloney chambers. By transferring the cells to a small volume of chilled, filtered seawater in clean Sedgewick-Rafter or PalmerMaloney chambers, each cell was washed at least 3 times to remove contamination from other cells and from residual ${ }^{14} \mathrm{C}$. We learned from earlier trials that small phytoplankton cells in high abundance could contaminate the isolations to a high degree, making it necessary to wash each isolated cell several times in filtered seawater before it was placed into a scintillation vial. Between 15 and 50 cells of the same species were placed in each of 4 replicate scintillation vials containing $2 \mathrm{ml}$ of Whatman GF/C filtered seawater. Blanks were taken by micro-pipetting water without cells from the last slide and placing as many drops into the scintillation vials as the corresponding number of picked cells. The scintillation vials were then filled with $10 \mathrm{ml}$ scintillation cocktail (Insta-Gel, Packard Inc.) and counted in a 1108 Beckman Liquid Scintillator.

Nutrients were added to the bottles in the following proportions: Expt 1: $\mathrm{NO}_{3}, 10 \mu \mathrm{M} ; \mathrm{PO}_{4}, 0.5 \mu \mathrm{M}$; Expts 2 and 3: $\mathrm{NO}_{3}, 5 \mu \mathrm{M} ; \mathrm{PO}_{4}, 0.5 \mu \mathrm{M}$. Vitamins and trace metals were added according to F/10 (Guillard \& Ryther 1962) in Expt 1 and as F/20 in Expts 2 and 3.

Phytoplankton cell counts in initial samples (before addition of ${ }^{14} \mathrm{C}$ ) and at the end of the experiment (after acidifying some samples and bubbling them with air to remove remaining inorganic ${ }^{14} \mathrm{C}$ ) were performed following the Utermöhl (1958) method. Cell volumes were estimated through measurements of the cell size and shape of 5 to 10 cells of each species and stoichiometric formulas as described in Edler (1979). To convert $\mu \mathrm{m}^{3}$ to $\mathrm{pg} C$ the conversion factor 0.13 was used (Smetacek 1975).

Prior to running the main experiments, an experiment was performed in 1991 to check if Dinophysis species were able to take up radioactively labeled inorganic carbon in the dark (without any prior light incubation). The natural algal communities were inoculated with $1 \mu \mathrm{Ci} \mathrm{ml}{ }^{-1}{ }^{14} \mathrm{C}$-labeled carbon and placed in the dark for $12 \mathrm{~h}$. After this period single cells of different algal species including all 3 photosynthetic Dinophysis species were picked and placed in scintillation vials containing $2 \mathrm{ml}$ of Whatman GF/C filtered seawater.

The amount of total inorganic carbon incorporated per cell $\left(\Delta \mathrm{C}_{\mathrm{i}}\right)$ was calculated as follows:

$$
\Delta \mathrm{C}_{\mathrm{i}}=\left[\left(\mathrm{DPM}_{\mathrm{cel}} / \mathrm{DPM}_{\mathrm{added}}\right) \cdot I C \cdot k_{1} \cdot k_{2} \cdot k_{3}\right] / t
$$

where DPM $_{\text {cell }}=$ DPM (disintegrations per minute) obtained for each vial (corrected for background DPM) and divided by the number of cells per vial; DPM ${ }_{\text {added }}=$ added DPM ${ }^{-1}$ (determined by dilution of the amount of added isotope and counting in the liquid scintillator) $\quad I C=$ concentration of total dissolved inorganic carbon $\left(\mathrm{mg} \mathrm{l}^{-1}\right.$ ), determined from tables (ErtebjergNielsen \& Bresta 1984) after measuring $\mathrm{pH}$, temperature, and salinity; $k_{1}=$ correction factor for respiration (1.06) (Ertebjerg-Nielsen \& Bresta 1984); $k_{2}=$ correction factor for slower uptake of ${ }^{14} \mathrm{C}$ than for ${ }^{12} \mathrm{C}$ (1.05) (Ertebjerg-Nielsen \& Bresta 1984); $k_{3}=$ conversion factor to get carbon assimilated per cell in pg $\left(10^{9}\right)_{i}$ and $t=$ time $(\mathrm{h})$.

We have assumed that the incorporated radioactive carbon during the first light period $(<8 \mathrm{~h}$ ) of the experiment was only in inorganic form and calculated ${ }^{14} \mathrm{C}$ uptake as carbon incorporated per cell for this time period (see Table 1). However, after this time period, the uptake could either have been in inorganic form 

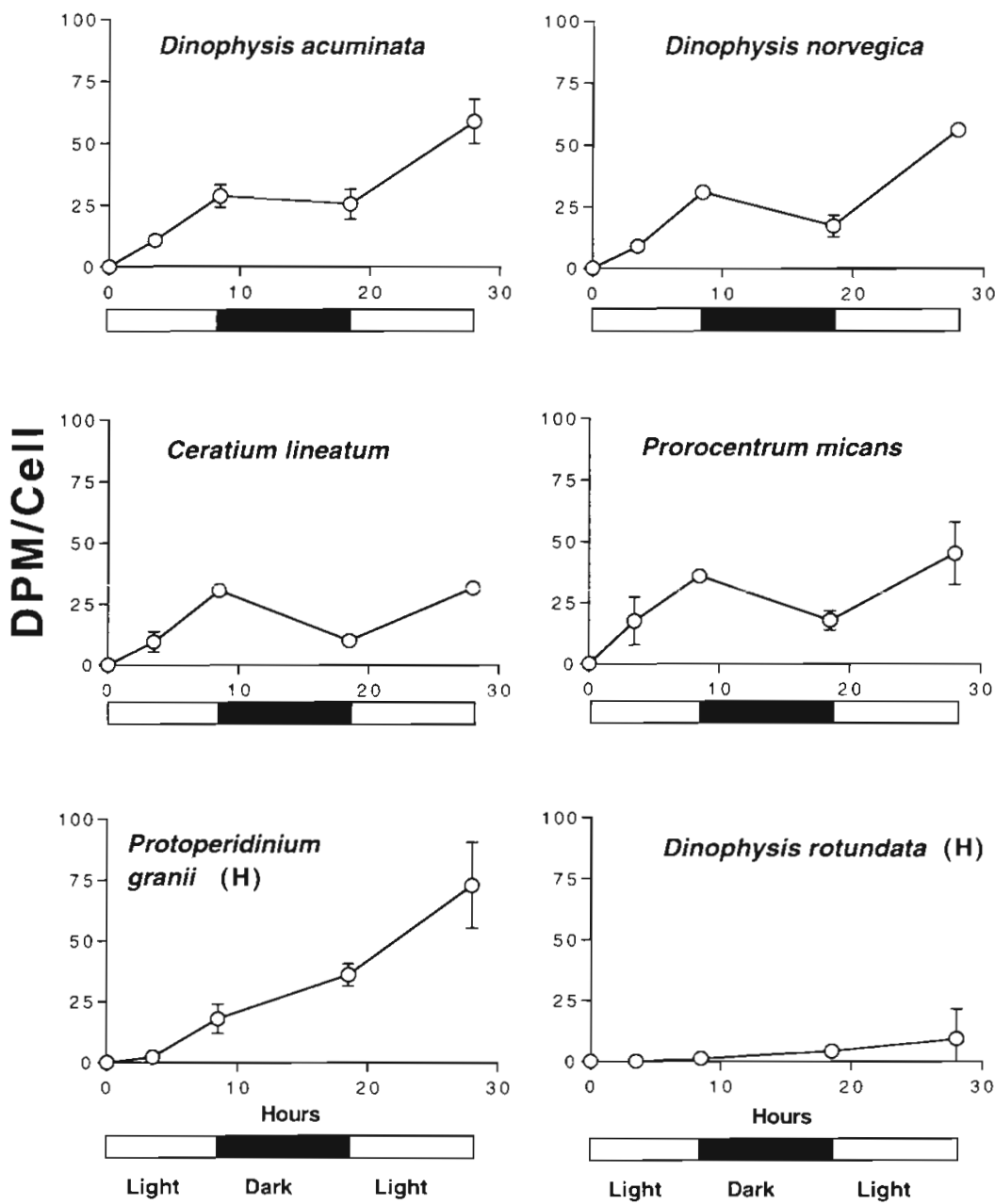

Fig. 1. Expt 1, water from the Tjärnö Strait, October $1992 .{ }^{14} \mathrm{C}$ uptake by different dinoflagellate species after exposure of a natural plankton community to light and dark incubations. Cells were isolated under the microscope and placed in scintillation vials. Each point is the mean \pm SD of 4 scintillation vials, each vial containing 15 to 50 cells. $\mathrm{H}$ : species that are completely heterotrophic

light:dark cycle of 10:14 h, with no increase of cell carbon in the dark. Thus

$$
\mu=\frac{\ln \left(m+\Delta C_{\mathrm{i} 2}\right)-\ln (m)}{t_{2}-t_{1}}
$$

where $m=$ cell carbon at $t_{1}$ (calculated from measured cell volumes) and $\Delta \mathrm{C}_{\mathrm{i} 2}=$ amount of labeled carbon incorporated per cell after $t_{2}-t_{1}$ hours. It should be stressed that this calculated division rate is based on the uptake of inorganic carbon only for the first light period (less than $8 \mathrm{~h}$ of incubation).

\section{RESULTS}

\section{Phytoplankton community composition}

During the occasions when the 3 experiments were performed, the phytoplankton communities were dominated by dinoflagellates, representing Skagerrak waters typical for the autumn season. In the water collected for Expts 1 and 2, before concentration, Dinophysis species constituted a very small percentage of the total phytoplankton biomass (both as cell numbers and as carbon). The maximum cell numbers found in situ in Expts 1 and 2

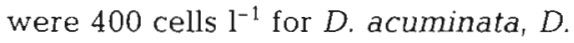
norvegica and $D$. acuta together. These cell numbers represented $0.28 \%$ of the total phytoplankton carbon and $0.32 \%$ of the total dinoflagellate carbon. During Expt 3 however, D. norvegica and

(incorporated by photosynthesis) or in organic form (incorporation of secondarily labeled organic compounds by heterotrophy). We have therefore chosen to express the results obtained from the longer incubations (including dark periods) only as DPM cell ${ }^{-1}$.

Specific growth rates ( $\mu$ ) were calculated on the basis of the theoretical time neressary for each species to double its carbon content based on the ${ }^{14} \mathrm{C}$ uptake during the first hours of incubation in light. Thus for Dinophysis acuminata, cell carbon was estimated to be $1194 \mathrm{pg} \mathrm{C}$ cell $^{-1}$ (by the measurements of its linear dimensions, calculation of volume and multiplying with the conversion factor mentioned before), so the calculated time for $D$. acuminata to accumulate carbon corresponding to $2388 \mathrm{pg} \mathrm{C}$ cell ${ }^{-1}$, would be the theoretical time for 1 division. In the calculation of $\mu$ it was assumed that the cells were subjected to a theoretical
D. acuta together reached densities up to 18000 cells $\mathrm{I}^{-1}$, representing up to $5 \%$ of the total phytoplankton carbon. In 1992 Gyrodinium aureolum and Ceratium species ( $C$. furca, $C$. lineatum, $C$. tripos and $C$. fusus) comprised the bulk of the dinoflagellate and phytoplankton cell carbon. During 1992 the diatom Pseudonitzschia pseudodelicatissima bloomed. Cell numbers were very high but this small species did not make up more than $10 \%$ of the total phytoplankton biomass. During 1993 the dinoflagellate C. furca constituted up to $94 \%$ of the total phytoplankton carbon.

\section{Light uptake of carbon}

The ${ }^{14} \mathrm{C}$ uptake, expressed as DPM cell ${ }^{-1}$, varied among species and between years (Figs, 1 to 3). The 
highest carbon uptake values (calculated from uptake of inorganic carbon during the first hours of incubation in light) for the different phytoplankton species were: Dinophysis acuta $62 \pm 19$ (mean \pm SD, Expt 2), D. acuminata $40 \pm 4$ (Expt 1), D. norvegica $108 \pm 11$ (Expt 1), Ceratium lineatum $29 \pm 15$ (Expt 2), C. furca $148 \pm$ 29 (Expt 3), C. tripos $34 \pm 11$ (Expt 2) pg C cell ${ }^{-1} \mathrm{~h}^{-1}$, respectively (Table 1 ). For the heterotrophic dinoflagellates, the equivalent values were: Protoperidinium granii $7.7 \pm 4.2$ (Expt 1), P. divergens $5.2 \pm 0.3$ (Expt 3 ) and Dinophysis rotundata $13.7 \pm 6.8$ (Expt 2$) \mathrm{pg} \mathrm{C}$ cell ${ }^{-1} \mathrm{~h}^{-1}$ respectively (Table 1 ). The maximum carbon uptake values for $D$. acuta and $D$. acuminata were almost the same for the different experiments; however, D. norvegica had a much higher carbon uptake during Expts 1 and 2 than in Expt 3 (Table 1).

\section{Dark uptake of carbon}

In the September 1991 experiment to check for possible uptake of radioactively labeled inorganic carbon in the dark (without any prior light incubation) by the Dinophysis species, there was no uptake of inorganic radioactive carbon for any of the species. The radioactivity in all the scintillation vials containing the phytoplankton cells was at the same level (about 50 DPM) as the background or the blanks (water pipetted from the last rinse of the cells; volume corresponding to the pipetting of 50 cells) (Table 2 ).

In Expts 1 and 2 (1992) the dark ${ }^{14} \mathrm{C}$ uptake for the Dinophysis species varied from low to negligible or even negative, in relation to the uptake in light (Figs. 1 \& 2). However, during Expt 3 (1993), the ${ }^{14} \mathrm{C}$ uptake by the Dinoph$y$ sis cells in the bottle exposed to the dark (Bottle B) without mixing was significantly higher than in Bottle $A$, incubated in the light for the same period. Dinophysis species in the dark bottle reached maximum uptake values which were sometimes significantly higher than the uptake values for cells exposed to light in Bottle A (Mann-
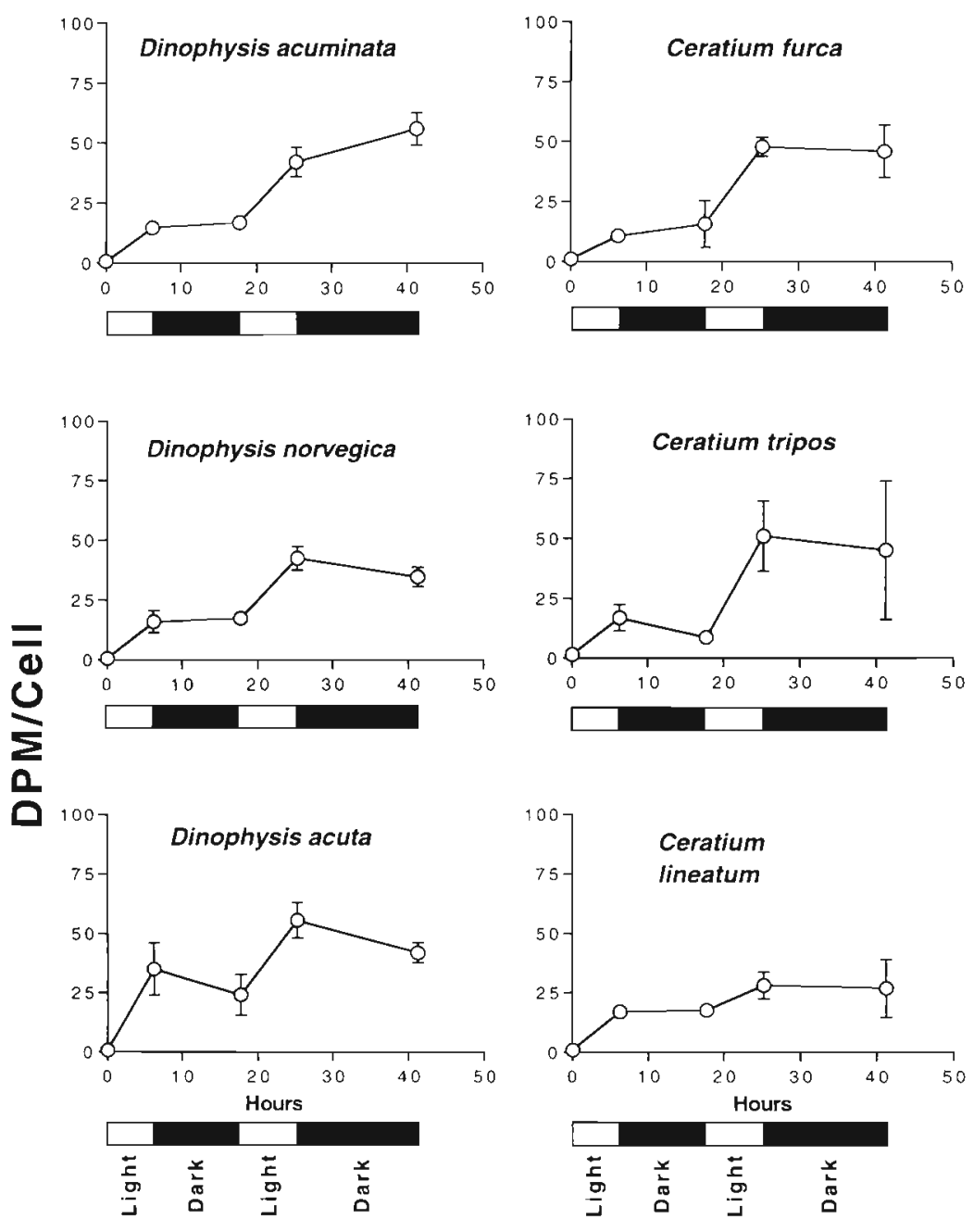

Fig. 2. Expt 2. Conditions as in Expt 1

Table $1 .{ }^{14} \mathrm{C}$ uptake (pg C cell-1 $\mathrm{h}^{-1}$ ) by different dinoflagellates after the first hours of incubation (in light) of the natural plankton communities. Dinoflagellate cells were isolated under the microscope and placed in scintillation vials. Each value represents the mean \pm SD of 4 scintillation vials, each vial containing 15 to 50 cells. Expts 1 and 2: water from the Tjärnö Strait, October 1992. Expt 3: water from the Gullmar Fjord, September 1993. A: autotrophic species; $H$ : heterotrophic species; $M$ : possibly mixotrophic species

\begin{tabular}{lccc|}
\hline Species & Expt 1 & Expt 2 & Expt 3 \\
\hline Dinophysis acuminata (M) & $40.12 \pm 4.3$ & $31.22 \pm 4.0$ & - \\
D. acuta (M) & - & $61.81 \pm 18.5$ & $50.79 \pm 5.6$ \\
D. norvegica (M) & $107.61 \pm 11.3$ & $32.23 \pm 7.1$ & $18.22 \pm 2.7$ \\
Ceratium furca (A) & - & $21.69 \pm 1.1$ & $148.31 \pm 28.7$ \\
C. lineatum (A) & $26.53 \pm 5.4$ & $28.66 \pm 14.5$ & - \\
C. tripos (A) & - & $34.34 \pm 10.6$ & - \\
D. rotundata (H) & $0.07 \pm 0.3$ & $13.70 \pm 6.8$ & - \\
Protoperidinium granii $(\mathrm{H})$ & $7.68 \pm 4.2$ & - & - \\
P. divergens (H) & - & - & $5.23 \pm 0.3$ \\
\hline
\end{tabular}



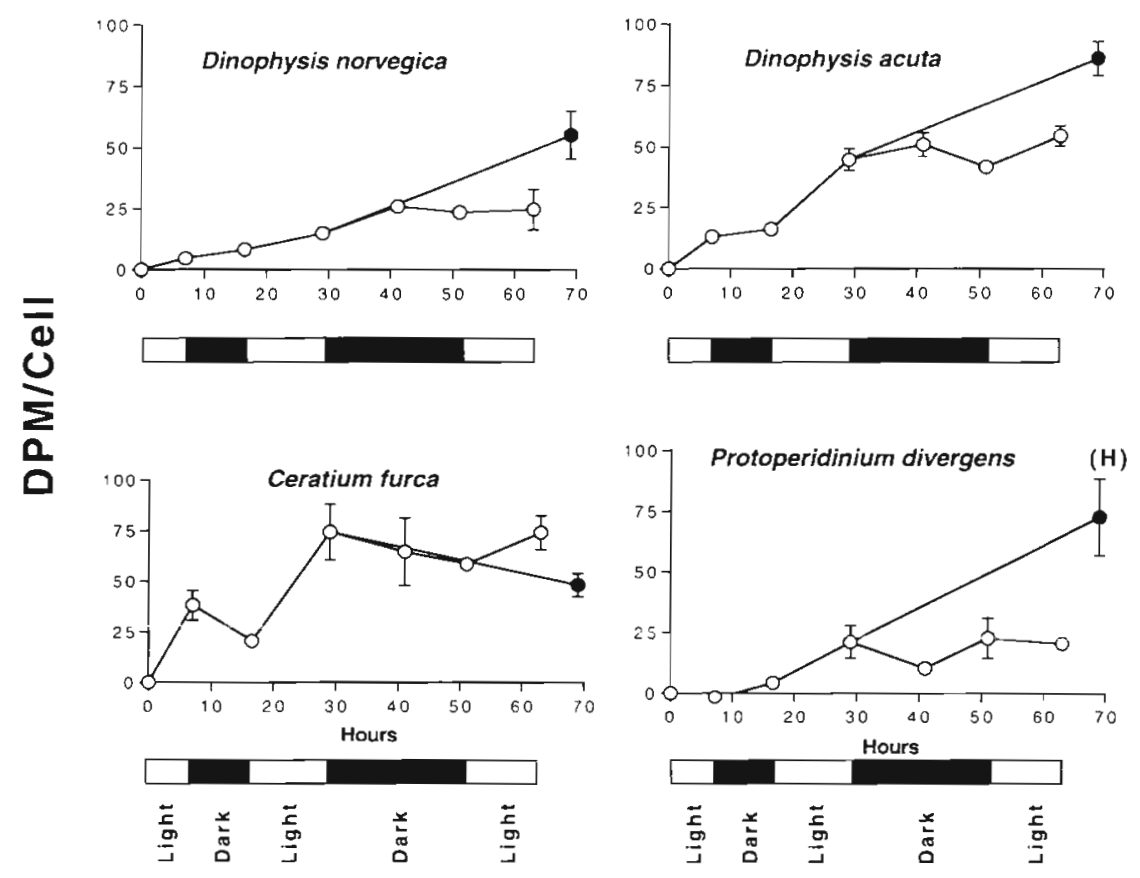

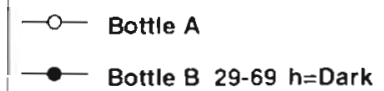

Fiq. 3. Expt 3. Conditions as in Expt 1 except that the water came from the Gullmar Fjord. September 1993. The Bottle $\mathrm{B}$ was in the dark between 29 and $69 \mathrm{~h}$ without sampling
Whitney $U$-test, $\mathrm{p}<0.05)$. For example, $D$. norvegica assimilated 1.0 DPM cell ${ }^{-1} \mathrm{~h}^{-1}$ during the dark incubation and 0.1 DPM cell-1 $\mathrm{h}^{-1}$ in the light bottle. The difference was not so marked for D. acuta. During the first hours of incubation in the light, this species seems to have been in better condition than $D$. norvegica. Thus D. acuta assimilated 1.8 DPM cell ${ }^{-1} \mathrm{~h}^{-1}$ in the light. The high dark uptake values found for $D$. norvegica in Bottle B might reflect the lack of mixing for that bottle. In the light bottles and in other dark bottle experiments,

Table 2. Radioactivity (DPM) in vials containing either dinoflagellate cells or the water surrounding the cells (blank, corresponding to the water volume when 50 cells were pipetted from the last rinse) or just the scintillation cocktail plus filtered non-radioactive water (background). The natural phytoplankton communities from the Gullmar Fjord (September 1991) were exposed to $12 \mathrm{~h}$ dark and radioactively labeled inorganic carbon $\left(1 \mu \mathrm{Ci} \mathrm{m} l^{-1}\right.$ of sample) before cell isolation

\begin{tabular}{|lcc|}
\hline Species & Cells/vial & $\begin{array}{c}\text { DPM/vial } \\
(\mathrm{n}=4 \text { vials })\end{array}$ \\
\hline Background & & 52.1 \\
Blank & & 53.2 \\
Dinophysis acuminata & 63 & $52.9 \pm 7.1$ \\
D. acuta & 50 & $52.4 \pm 9.5$ \\
D. norvegica & 50 & $53.6 \pm 10.6$ \\
Ceratium furca & 50 & $52.6 \pm 5.2$ \\
C. Lneatum & 50 & $52.6 \pm 14.2$ \\
C. tripos & 50 & $53.4 \pm 8.9$ \\
D. rotundata & 42 & $53.1 \pm 4.6$ \\
Protoperidinium granii & 50 & $52.5 \pm 4.8$ \\
P. divergens & 50 & $53.4 \pm 5.2$ \\
\hline
\end{tabular}

cells were mixed prior to each sampling, and this is well known to be inhibitory to certain dinoflagellates (e.g. Thomas \& Gibson 1990).

The uptake of ${ }^{14} \mathrm{C}$ by Dinophysis acuta and $D$. norvegica in the dark (Bottle $B$ ) was the same as the maximum uptake for the heterotrophic dinoflagellate Protoperidinium divergens (1.3 DPM cell ${ }^{-1} \mathrm{~h}^{-1}$ ). Ceratium species had both negative and positive carbon uptake in the dark (Figs. 1 to 3 ).

\section{Growth rates}

Growth rates $(\mu)$, estimated from carbon uptake during the first incubation hours in relation to cell carbon content, varied for the 3 experiments for the different Dinophysis species (Table 3 ). The maximum growth rates $\left(\mu, \mathrm{d}^{-1}\right)$ for $D$. acuminata, $D$. norvegica and $D$. acuta were $0.59 \pm 0.13,0.63 \pm 0.15$, and $0.41 \pm 0.04$, respectively.

\section{DISCUSSION}

Measurement of in situ growth rates for individual species among complex phytoplankton communities is not an easy task (Furnas 1990). Rivkin \& Seliger (1981) first used the method of incubating the entire phytoplankton communities with radioactive ${ }^{1.4} \mathrm{C}$ labeled carbon followed by single cell isolation of certain species in order to obtain the carbon fixation rate of these species growing in their normal environment. After this 
Table 3. Growth rates (specific $\mu$ ) for the different dinoflagellate species, based on carbon uptake per cell for the first hours $(<8 \mathrm{~h})$ of incubation (light period only). Each value is a mean $\pm \mathrm{SD}$ for 4 replicate vials. H: species that are completely heterotrophic

\begin{tabular}{|lccc|}
\hline Species & Expt 1 & Expt 2 & Expt 3 \\
\hline Dinophysis acuminata & $0.59 \pm 0.13$ & $0.49 \pm 0.05$ & - \\
D. acuta & - & $0.41 \pm 0.04$ & $0.35 \pm 0.06$ \\
D. norvegica & $0.63 \pm 0.15$ & $0.29 \pm 0.06$ & $0.18 \pm 0.05$ \\
Ceratium furca & - & $0.28 \pm 0.01$ & $0.60 \pm 0.08$ \\
C. lineatum & $0.48 \pm 0.09$ & $0.81 \pm 0.22$ & - \\
C. tripos & - & $0.17 \pm 0.02$ & - \\
D. rotundata $(\mathrm{H})$ & $0.001 \pm 0.001$ & $0.01 \pm 0.01$ & - \\
Protoperidinium granii $(\mathrm{H})$ & $0.008 \pm 0.003$ & - & - \\
P. divergens $(\mathrm{H})$ & - & - & $0.03 \pm 0.00$ \\
\hline
\end{tabular}

initial work, a series of experiments was performed in order to estimate not only the carbon uptake, but heterotrophic behavior for different phytoplankton species as well (Rivkin 1985, Rivkin \& Voytek 1985, 1986. Rivkin \& Putt 1987). Here we used the single cell isolation method to investigate carbon uptake by natural phytoplankton communities, including several enigmatic Dinophysis species for which nutrition is poorly understood. By measuring uptake repeatedly during both the light and the dark, it was hoped that signs of mixotrophic nutrition could be detected through positive and increasing uptake during the dark when photosynthetic uptake would not be possible. For the 3 Dinophysis species examined, carbon uptake in the light was roughly equivalent to that of photosynthetic dinoflagellates such as Ceratium. No clear trend was observed for the dark periods, however. Sometimes the Dinophysis cells behaved like other photosynthetic species, decreasing their carbon quota through respiration. On other occasions, however, especially in one experiment when the dark bottle was left undisturbed for $40 \mathrm{~h}$, dark uptake of carbon was significant. These experiments have not resolved the enigma of Dinophysis nutrition, but the results do suggest that mixotrophy may be occurring for several species.

\section{${ }^{14} \mathrm{C}$ uptake}

Carbon uptake for the different dinoflagellates in our experiments varied from year to year but, as expected, the maximum carbon uptake in the light was mostly dependent on cell size. For the large Ceratium furca, a maximum rate of $148 \mathrm{pg} \mathrm{C}$ cell $^{-1} \mathrm{~h}^{-1}$ was found during Expt 3. This species did not seem to be in good condition during Expt 2 when a lower carbon uptake was recorded $\left(22 \mathrm{pg} \mathrm{C} \mathrm{cell}^{-1} \mathrm{~h}^{-1}\right)$. C. lineatum had low carbon uptake in Expts 1 and 2 ( 26 and $29 \mathrm{pg} \mathrm{C}$ cell $^{-1} \mathrm{~h}^{-1}$ ) compared to values found by Rivkin \& Voytek (1985), who reported 55 to $78 \mathrm{pg} \mathrm{C} \mathrm{cell}^{-1} \mathrm{~h}^{-1}$ for this species. The smallest of the species we studied, Dinophysis acuminata, had an uptake of 31 to $40 \mathrm{pg} \mathrm{C}$ cell $^{-1} \mathrm{~h}^{-1}$. This is higher than rates reported by Berland et al. (1994), but similar to those of Berland et al. (1995b) (26 pg C cell $\mathrm{Ch}^{-1}$ ). Carbon uptake by $D$. acuta in our Expts 2 and 3 was 62 and 51 pg $\mathrm{C}$ cell $^{-1} \mathrm{~h}^{-1}$, respectively. Subba Rao \& Pan (1993), using the same method as we did, found uptake rates for $D$. norvegica varying between 16 and $25 \mathrm{pg} \mathrm{C} \mathrm{Cell}^{-1}$ $\mathrm{h}^{-1}$, which is in the same range as the values found by us in Expts 2 and 3 (32 and $18 \mathrm{pg} \mathrm{C} \mathrm{cell}^{-1} \mathrm{~h}^{-1}$, respectively). However, our value for the $D$. norvegica in Expt 1 was much higher (108 pg C cell ${ }^{-1} \mathrm{~h}^{-1}$ ). In summary, the different dinoflagellate species exhibited different carbon uptake from experiment to experiment, presumably as a result of their different physiological status at the start of the incubations as well as the different conditions of the incubations themselves. Since these were natural communities under study, nutrient limitation or other stresses were likely, and cells would not be expected to respond equally fast to the nutrient enrichments and laboratory incubation conditions.

\section{Heterotrophy}

Our experiments were designed to reveal mixotrophic behavior through the uptake of labeled carbon during the dark. The pattern to be expected is exactly that exhibited by the exclusively heterotrophic Protoperidinium species and Dinophysis rotundata used in our experiments (Figs. 1 \& 3). The insignificant initial carbon uptake in the light was followed by a significant and steady increase in the dark, a result of the consumption of labeled photosynthetic algae which only became a significant fraction of the labeled biomass after several hours of light exposure. The Dinophysis species in our experiments did not show this consistent behavior, although signs of dark uptake were observed. Care was taken throughout to have numerous replicates and several time points for each light or dark period in order to better resolve trends. Even with this care and the experience and improvement in precision gained from repeated experiments, dark uptake was significant on some, but not all, occasions. The most significant results are for $D$. acuminata in Expt 2 (Fig. 2) and D. norvegica and D. acuta in Expt 3 (Fig. 3). The most notable dark uptake was observed in a modification of our normal experimental protocol 
when the dark bottle was left unsampled for an extended interval. Then, $D$. norvegica showed a high dark uptake, significantly higher than for the same species in the light (Fig. 3). This result suggests that the repeated mixing and subsampling from our experimental flasks may have inhibited the uptake process. The negative effects of turbulence on dinoflagellates is well known (e.g. Thomas \& Gibson 1990).

Another explanation for the high dark uptake by Dinophysis norvegica observed in Expt 3 is that heterotrophy may be induced by prolonged exposure to low light, as has been reported by other authors (e.g. Jones et al. 1995) either through a stimulation of auxotrophy (Pintner \& Provasoli 1968, Rivkin \& Putt 1987) or phagotrophy (Jones et al. 1993). However, inhibition of the bacterivory of a freshwater Chrysophyte exposed to darkness or low light has also been found (Caron et al. 1993).

Until recently, within the genus Dinophysis, only the non-pigmented $D$. rotundata was known to be heterotrophic (Hansen 1991). However, Jacobson \& Andersen (1994) used transmission electron microscopy to demonstrate the existence of food vacuoles in $D$. norvegica and $D$. acuminata. Although these authors could not identify the prey inside the vacuoles, the particles inside $D$. acuminata vacuoles resembled those in the totally heterotrophic Oxyphysis oxytoxoides, suggesting that $D$. acuminata was preying on ciliates. Berland et al. (1995a) found no food vacuoles in $D$. acuminata, but did observe a tongue-like structure in the flagellar region that had the appearance of an atrophied peduncle. These authors believe this apparatus might be involved in nutrition. Reguera et al. (1995) believe it may function in sexual reproduction. Carpenter et al. (1995) found $D$. norvegica in high concentrations during the summer of 1992 and 1993 at depths of 12 to $15 \mathrm{~m}$ in the Baltic Sea. Measurements of their photosynthesis showed that the cells would take 4 to 9 mo to double their cellular carbon (if based only on inorganic carbon uptake). The doubling time for this species has been found by us (in this article) and by other authors to reach 0.2 to $0.7 \mathrm{~d}^{-1}$ (Berland et al. 1995b, Subba Rao \& Pan 1993, Granéli et al. 1995). Thus as Carpenter et al. (1995) concluded, mixotrophy seems to be the cxplanation for growth of $D$ norvegira in situations when photosynthesis cannot provide sufficient carbon. In the Kattegat $D$. norvegica increased from 700-1000 cells $l^{-1}$ at the beginning of October to 3500-9000 cells $l^{-1}$ at the beginning of December 1995 (1. to $5 \mathrm{~m}$ depth-integrated water samples), when the

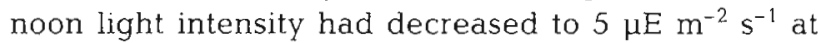
$1 \mathrm{~m}$ depth (Per Olsson, TOXICON, Landskrona, Sweden, pers. comm.). Once again, this suggests that this species may survive (and even grow) through difficult periods using mixotrophy.
Among the other photosynthetic dinoflagellates investigated by us, Ceratium furca and $C$. lineatum were the only species that exhibited possible carbon uptake in the dark (Fig. 3). Chang \& Carpenter (1994) found inclusion bodies that stained with a DNAspecific fluorochrome in several species of Ceratium from the Caribbean Sea. Among the individuals containing inclusion bodies were cells of $C$. furca. The authors, however, could not definitively conclude whether these inclusion bodies were from ingested phytoplankton, bacteria cells, or were due to parasites. However, in cells of $C$. furca collected from Chesapeake Bay, USA, Bockstahler \& Coats (1993) were able to identify the remains of ingested oligotrich ciliates.

\section{Cell division rates}

Growth rates were calculated for our targeted species using carbon uptake rates determined during the first few hours of light. We chose not to calculate these rates over longer intervals since we could not be sure the uptake was from the inorganic carbon pool, of which we knew the specific activity. It is possible that some of the cells divided during the first incubation period in light. In this instance, inadvertant isolation of recently divided cells would give an underestimation of the true growth rate, since those cells would be small and consequently would contain less radioactively labeled carbon than 'normal', larger cells. Carpenter et al. (1995) found that Dinophysis norvegica divided asynchronously, so cell division may have occurred at any time during our experiments.

In our experiments, Ceratium lineatum, $C$. furca and C. tripos had maximum growth rates of $0.81,0.60$ and $0.17 \mathrm{~d}^{-1}$, respectively. Rivkin \& Voytek (1986) found maximum division rates for 5 Ceratium species, including $C$. tripos, isolated from the Chesapeake Bay to vary between 0.20 and 0.31 doublings $\mathrm{d}^{-1}$ or 0.14 to $0.21 \mathrm{~d}^{-1}$ $(\mu)$ which is in the same range as or lower than our values for different Ceratium species. These authors also found that $C$. tripos isolated from coastal waters grew twice as fast as the same species isolated from the mouth of Chesapeake Bay, i.e. $\mu=0.34$ versus $0.18 \mathrm{~d}^{-1}$. Thus our values for that species $\left(\mu=0.17 \mathrm{~d}^{-1}\right)$ are similar to those of Rivkin \& Voytek (1986)

Dinophysis acuminata and $D$. norvegica had similar maximum growth rates of 0.59 and $0.63 \mathrm{~d}^{-1}$, respectively. For $D$. acuta the maximum growth rate was $0.41 \mathrm{~d}^{-1}$. Our estimates of $D$. acuminata growth rates are thus similar to those of Chang \& Carpenter (1991) estimated for $D$. acuminata using the mitotic index approach on natural phytoplankton communities in Long Island Sound, USA. These authors found $D$. acuminata to grow at 0.53 and $0.67 \mathrm{~d}^{-1}$. Subba Rao \& 
Pan (1993) also measured ${ }^{14} \mathrm{C}$ uptake by $D$. norvegica, but did not calculate the growth rate for this species.

\section{Summary}

This study provides several insights into the nutrition of Dinophysis species, which remains largely unknown. First, our results make it clear that $D$. norvegica, $D$. acuta, and $D$. acuminata are all capable of photosynthetic carbon uptake rates and growth rates in the light that are comparable to rates for other autotrophic dinoflagellate species and that are consistent with published measurements for these species. Mixotrophy, which could only have been detected during the dark intervals using our methods, was indicated on several occasions with these species but, as is common with Dinophysis, the results were variable and inconsistent. Since natural communities were studied, the prior nutritional history of the cells and the extent to which those cells were capable of heterotrophic uptake at the time of the experiments could neither be known nor controlled. The strongest evidence for mixotrophic uptake comes from a population that was kept in the dark for $40 \mathrm{~h}$, suggesting that mixotrophy may be induced only when photosynthesis is not able to meet the needs of the cells. This is consistent with the observations of Carpenter et al. (1995) on a subsurface population of $D$. norvegica that was persisting in the Baltic despite photosynthetic rates that were exceedingly low. All of these data suggest that the heterotrophy of Dinophysis species may be a means to survive unfavorable conditions, or to provide some special compound found only in organic material. This also may explain the lack of success in the many efforts to culture these organisms in the laboratory (Sampayo 1993, Maestrini et al. 1995). Uptake of particulate or dissolved organic carbon under conditions of darkness or low light may allow these species to maintain high cell numbers under adverse conditions, as exemplified by the high cell numbers found for $D$. acuta and $D$. norvegica during the 'low-light' winter in the Kattegat and Skagerrak (Pettersson 1994, Per Olsson pers. comm.J.

Acknowledgements. Our thanks to Christer Nylander, Department of Marine Ecology, Lund, for the calculations of carbon uptake, growth rates and statistics. Thanks to Roger Finlay who corrected our English. This study was supported by funds (to E.G.) from the Swedish Board for Agricultural and Forestry Research (SJFR) and the Swedish Natural Science Research Council (NFR), and by the National Science Foundation through award OCE-9415536 (to D.M.A.). The 'Programme National Efflorescences Algales toxiques' (France) provided funds (to S.Y.M.). This is contribution no. 9459 from the Woods Hole Oceanographic Institution.

\section{LITERATURE CITED}

Ertebjerg-Nielsen G, Bresta AM (1984) Guidelines for the measurement of phytoplankton primary production, 2nd edn. BMB Publ no. 1 The Baltic Marine Biologists, Charlottenlund

Berland BR, Maestrini SY, Bechemin C, Legrand C (1994) Photosynthetic capacity of the toxic dinoflagellates Dinophysis of. acuminata and Dinophysis acuta. La Mer 32: $107-117$

Berland BR, Maestrini SY, Grzebyk D (1995a) Observations on possible lifecycle stages of the dinoflagellate Dinophysis cf. acuminata, Dinophysis acuta and Dinophysis pavillardi. Aquat Microb Ecol 9:183-189

Berland BR, Maestrini SY, Grzebyk D, Thomas P (1995b) Recent aspects of nutrition in the dinoflagellate Dinophysis cf. acuminata. Aquat Microb Ecol 9:191-198

Bockstahler KR, Coats DW (1993) Spatial and temporal aspects of mixotrophy in Chesapeake Bay dinoflagellates. J Euk Microbiol 40:46-60

Bonin DJ, Maestrini SY (1981) Importance of organic nutrients for phytoplankton growth in natural environments: implications for algal species succession. In: Platt T (ed) Physiological bases of phytoplankton ecology. Can Bull Fish Aquat Sci, Ottawa, p 270-291

Carlsson P, Granéli E, Finenko G, Maestrini SY (1995) Copepod grazing on a phytoplankton community containing the toxic dinoflagellate Dinophysis acuminata. J Plankton Res 17:1925-1938

Caron DA, Sanders RW, Lim EL, Marrasé C, Amaral LA, Whitney S, Aoki KG, Porter KG (1993) Light-dependent phagotrophy in the freshwater mixotrophic Chrysophyte Dinobryon cylindricum. Microb Ecol 25:93-111

Carpenter EJ, Jansson S, Boje R, Pollehne F, Chang J (1995) The dinoflagellate Dinophysis norvegica: biological and ecological observations in the Baltic Sea. Eur J Phycol 30: $1-9$

Chang F, Carpenter EJ (1991) Species-specific phytoplankton growth rates via diel DNA synthesis cycles. V. Application to natural populations in Long Island Sound. Mar Ecol Prog Ser $78: 115-122$

Chang F, Carpenter EJ (1994) Inclusion bodies in several species of Ceratium Schrank (Dinophyceae) from the Caribbean Sea examined with DNA-specific staining. J Plankton Res 16:197-202

Delmas D, Herbland A, Maestrini SY (1992) Environmental conditions which lead to increase in cell density of the toxic dinoflagellates Dinophysis spp. in nutrient-rich and nutrient-poor waters of the French Atlantic coast. Mar Ecol Prog Ser 89:53-61

Edler L (ed) (1979) Recommendations on methods for marine biological studies in the Baltic Sea-phytoplankton and chlorophyll. BMB Publ no. 5, The Baltic Marine Biologists, Charlottenlund

Edler L, Hageltorn M (1990) Identification of the causative organism of a DSP-outbreak on the Swedish west coast. In: Granéli E, Sundström B, Edler L, Anderson DM (eds) Toxic marine phytoplankton. Elsevier Science Co, Inc, New York, p 345-349

Edvardsen B, Moy F, Paasche E (1990) Hemolytic activity in extracts of Chrysochromulina polylepis grown at different levels of selenite and phosphate. In: Granéli E, Sundström $B$, Edler L, Anderson DM (eds) Toxic marine phytoplankton. Elsevier Science Co, Inc, New York, p 284-289

Furnas MJ (1990) In situ growth rates of marine phytoplankton: approaches to measurement, community and species growth rates. J Plankton Res 12:1117-1151 
Granéli E, Anderson DM, Carlsson P. Finenko G, Maestrini SY, Sampayo M de M, Smayda TJ (1995) Nutrition, growth rate and sensibility to grazing for the dinoflagellates Dinophysis acuminata, $D$. acuta and $D$. norvegica. La Mer 33 81-88

Granéli E, Edler L, Gedziorowska D, Nyman U (1985) Influence of humic and fulvic acids on Prorocentrum minimum In: Anderson DM, White AW, Baden DG (eds) Toxic dinoflagellates. Elsevier Science Publishing Co, New York, p 201-206

Granéli E, Haraldsson C (1993) Can an increased leaching of trace metals from acidified areas influence phytoplankton growth in coastal waters? Ambio 22:308-311

Granéli E, Risinger L (1994) Effects of cobalt and vitamin $B_{12}$ on the growth of the marine Prymnesiophyceae Chrysochromulina polylepis. Mar Ecol Prog Ser 113:177-183

Guillard RRL, Ryther JH (1962) Studies of marine planktonic diatoms. I. Cyclotella nana Hustedt and Detonula confervacea (Cleve) Gran. Can J Microbiol 8:229-239

Hallegraeff GM (1993) A review of harmful algal blooms and their apparent global increase. Phycologia 32:79-99

Hallegraeff GM, Lucas IAN (1988) The marine dinoflagellate genus Dinophysis (Dinophyceae): photosynthetic, neritic and non-photosynthetic, aceanic species. Phycologia 27 $249-258$

Hansen PJ (1991.) Dinophysis-a planktonic dinoflagellate genus which can act both as prey and a predator of a ciliate. Mar Ecol Prog Ser 69:201-204

Harrison PJ, Yu PW, Thompson PA, Price NM, Phillips DJ (1988) Survey of selenium requirements in marine phytoplankton. Mar Ecol Prog Ser 47:89-96

Jacobson DM, Andersen RA (1994) The discovery of mixotrophy in photosynthetic species of Dinophysis (Dinophyceae): light end electron microscopical observations of food vacuoles in Dinophysis acuminata, $D$. norvegica and two heterotrophic dinophysoid dinoflagellates. Phycologia 33:97-110

Jones HLJ, Durjun P, Leadbeater BSC, Green JC (1995) The relationship between photoacclimation and phagotrophy with respect to chlorophyll $a$, carbon and nitrogen content, and cell size of Chrysochromulina brevifilum (Prymnesiophyceae). Phycologia 34:128-134

Jones HLJ, Leadbeater BSC, Green JC (1993) Mixotrophy in marine species of Chrysochromulina (Prymnesiophyceae): ingestion and digestion of a small green flagellate. J Mar Biol Assoc UK 73:283-296

Keller MD, Guillard RRL (1985) Factors significant to marine dinoflagellate culture. In: Anderson DM, White AW, Baden DG (eds) Toxic dinoflagellates. Elsevier Science Publishers, New York, p 113-116

Krogh P, Edler L, Granéli E, Nyman U (1985) Outbreak of diarrhetic shellfish poisoning on the west coast of Sweden. In: Anderson DM, White AW, Baden DG (eds) Toxic dinoflagellates. Elsevier Science Publishers, New York, p 501-503

Lembeye G, Yasumoto T, Zhao J, Fernandez R (1993) DSP outbreak in Chilean fiords. In: Smayda TJ, Shimizu Y (eds) Toxic phytoplankton blooms in the sea. Elsevier Science Co, Inc, Amsterdam, p 525-529

Maestrini SY, Berland BR, Grzebyk D, Spano AM (1995) Dinophysis spp. cells concentrated from nature for experimental purposes, using size fractionation and reverse migration. Aquat Microb Ecol 9:177-182

Manton I, Parke M (1962) Preliminary observations on scales and their mode of origin in Chrysochromulina polylepis sp. nov. J Mar Biol Assoc UK 42:565-578
Nygaard K, Hessen DO (1990) Use of ${ }^{14} \mathrm{C}$-protein-labeled bacteria for estimating rates by heterotrophic and mixotrophic flagellates. Mar Ecol Prog Ser 68:7-14

Nygaard K, Tobiesen A (1993) Bacterivory in algae: a survival strategy during nutrient limitation. Limnol Oceanogr 38: $273-279$

Pettersson K (ed) (1994) Central information for the western seas of Sweden. Göteborg County Administration Board, Göteborg, No. 15 (in Swedish)

Pintner IJ, Provasoli L (1968) Heterotrophy in subdued light of 3 Chrysochromulina species. US-Japan seminar on Marine Microbiology. Bull Misaki Mar Biol Inst Kyoto Univ Proc 12:25-31

Porter KG (1988) Phagotrophic phytoflagellates in microbial food webs. Hydrobiologia 159:89-97

Reguera B, Bravo I, Fraga S (1995) Autoecology and some life history stages of Dinophysis acuta Ehrenberg. J Plankton Res 17:999-1015

Rivkin RB (1985) Carbon-14 labelling patterns of individual marine phytoplankton from natural populations. Mar Biol 89:135-142

Rivkin RB, Putt M (1987) Heterotrophy and photoheterotrophy by Antarctic microalgae: light-dependent incorporation of amino acids and glucose. J Phycol 23:442-452

Rivkin RB, Seliger HH (1981) Liquid scintillation counting for ${ }^{14} \mathrm{C}$ uptake of single cells isolated from natural samples. Limnol Oceanogr 26:780-785

Rivkin RB, Voytek MA (1985) Photoadaptation of photosynthesis by dinoflagellates from natural populations: a species approach. In: Anderson DM, White AW, Baden DG (eds) Toxic dinoflagellates. Elsevier Science Publishers, New York, p 97-102

Rivkin RB, Voytek MA (1986) Cell division rates of eucaryotic algae measured by Tritiated Thymidine incorporation into DNA: coincident measurements of photosynthesis and cell division of individual species of phytoplankton isolated from natural populations. J Phycol 22:199-205

Sampayo MdeM (1993) Trying to cultivate Dinophysis spp. In: Smayda TJ, Shimizu Y (eds) Toxic phytoplankton blooms in the sea. Elsevier Science Co, Inc, Amsterdam, p 807-810

Sedmak B, Fanuko N (1991) Occurrence of Dinophysis spp. and toxic shellfish in the Northern Adriatic. J Appl Phycol 3:289-294

Smetacek V (1975) Die Sukzession des Phytoplankton in der westlichen Kieler Bucht. PhD thesis, Institut für Meereskunde, Kiel

Subba Rao DV (1995) Life cycle and reproduction of the dinoflagellate Dinophysis norvegica. Aquat Microb Ecol 9: $199-201$

Subba Rao DV, Pan Y (1993) Photosynthetic characteristics of Dinophysis norvegica Claparede \& Lachmann, a red-tide dinoflagellate. J Plankton Res 15:965-976

Subba Rao DV, Pan Y, Zitko V, Bugden G, Mackeigan K (1993) Diarrhetic shcllfish poisoning (DSP) assnriated with a subsurface bloom of Dinophysis norvegica in Bedford Basin, eastern Canada. Mar Ecol Prog Ser 97:117-126

Thomas WH, Gibson CH (1990) Effects of small-scale turbulence on microalgae. J Appl Phycol 2:71-77

Utermöhl H (1958) Zur Vervollkommnung der quantitativen Phytoplankton Methodik. Mitt Int Verein Theor Angew Limnol 9:1-38

Yasumoto T, Oshima Y, Sugawara W, Fukuyo Y, Oguri $H_{\text {, }}$ Igarashi T, Fujita N (1980) Identification of Dinophysis fortii as the causative organism of Diarrhetic Shellfish Poisoning. Bull Jap Soc Sci Fish 46:1405-1411 